\title{
Improvement of the organizational-economic mechanism of resource-saving at the machine building enterprise
}

\section{Iryna Vovk $\mathbb{1} *$, Yuriy Vovk $\mathbb{1 0 * *}$, Oleh Lyashuk $* * *$}

* Ternopil Ivan Pul'uj National Technical University,

56 Ruska str., 46001 Ternopil, Ukraine

PhD, Assistant Professor, Department of Management of Innovation and Entrepreneurship

** Ternopil Ivan Pul'uj National Technical University,

56 Ruska str., 46001 Ternopil, Ukraine

PhD, Associate Professor, Department of Transport Technologies and Mechanics

*** Ternopil Ivan Pul'uj National Technical University,

56 Ruska str., 46001 Ternopil, Ukraine

Dr, Associate Professor, Head of Department of Automobiles

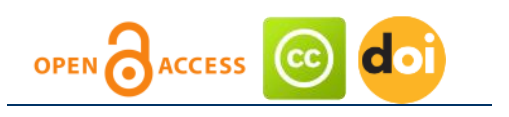

Article history:

Received: July 07, 2017

1st Revision: August 11,

2017

Accepted: October 5, 2017

\section{JEL classification: \\ L53 \\ 032 \\ Q55}

\section{DOI:}

10.14254/jems.2017.2-2.1

\begin{abstract}
The characteristic of the resource-saving at the machine-building enterprise has been presented. The complexity and system of the resource-saving control, as well as reasonableness of the development of the efficient organizational economic resourcesaving mechanism have been interpreted. It was testified that the basis of the successful activity strategy in the resource-saving at the local machinebuilding enterprises is the efficient application of the available resources according to the requirement of the manufacturing products. Efficiency of such control can result from the proper application of the resourcenomy levers as a new science. Innovation chain of investigation of the resource-saving control problems from the point of view of resourcenomy has been proposed. Determination of the most efficient ways of setting up the organizational economic mechanism of resource-saving basing on the qualitative and quantitative factors of the resources application, using the resourcenomy techniques and taking into account the possibility to provide the enterprise with technologies, staff, control system, as well as the influence of each of the factors of the outside and inside environment of the enterprise, has been presented.
\end{abstract}

Keywords: innovation chain of resourcenomy, organizational and economic mechanism, efficient use of resources, performance, resource, resourcenomy. 


\section{Introduction}

Complication of the resource-saving control process at the machine-building enterprise is characterised by the following:

1st - the process takes place within complicated dynamic system;

2nd - the subject of control affects complex object, which consists of different resources (material-raw resources, financial, informational, man-power, etc.);

$3 \mathrm{~d}$ - the resource-saving control process consists of numeral functional operations, which are carried out by different structural subdivisions of the enterprise, which interrelate between each other and the outside environment (control bodies, bank structures, industrial and transport enterprises, etc.).

Control of the resource-saving as the subdivision of the machine-building enterprise control is of the complex, system character, that is, control interrelations are of different types (political, social, economic, organizational, technical) according to the functions, which are carried out in the process of the resource-saving control.

\section{Analysis of the available investigations and publications}

Theoretical and scientific-methodical approaches to the control of the innovation resourcesaving policy at different levels of management have been studied in the papers of foreign and domestic scientists: Andrushkiv B., Kyrych N., Vovk Yu. (Andrushkiv et al., 2012), Doroguntsov S. I., Dolishiy M. I., Danylyshyn O. O., Illyashenko S. M., Sotnyk I. M. (Sotnyk, 2006), Medows D., Boulding K., Solou R., Titenberg T.; Taylor G., Rostou U., Odum G. and Y., Forrester G., Daily G., Ipolitova I., Holub I., etc.

The resource-saving within this investigation is treated as the process of material and power capacity of the product unit, decrease of costs in production, increase of the finishing goods while applying in the enterprise activity the scientific technological achievements and organizationaleconomic control mechanisms proposed by the resourcenomy as the science.

Scientific investigations, which deal with the reasonableness of application of different control methods, which raise the resource efficiency at the industrial enterprises, testify, that in the market economy the most efficient ones to stimulate the resource-saving on the microlevel are those the economic methods of control. The most acceptable strategy of the promising development of the machine-building complex of Ukraine should be the realization of the resourcesaving policy, which will result in the overcoming of the available organizational economic problems- imperfect legislative basis and system of the state bodies control of the resource-saving; lack of legal responsibility for the exceeding use of the resource; lack of experts in the resourcesaving, unavailability of the developed infrastructure in the resource-saving, insufficient application of the price policy, which is caused by the increase of the material-resource component of the product cost price, unfavorable investment policy, lack of funds for selection of the efficient resource-saving technologies; inefficient protection from unfair competition of the foreign producers (Sotnyk, 2006).

To realize the main challenges of the resource-saving policy at the machine-building enterprises of Ukraine it is necessary to improve the organizational-economic mechanism of the resource-saving, to apply efficiently available resources in the production and to protect environment. The common methodological approach to the determination, setting up and functioning of the mechanism for the resource-saving control, based on the consumption optimization of the joint resources, which result in the improvement of their application efficiency is not available. That is why the development of such mechanism is not only of the theoretical importance, but that of the practical one.

The notion "organizational economic control mechanism" concerning different economic objects is often used in modern scientific economic literature (Astapova G.V et al., 2001; Buleev, 1993; Yeryomenko-Grygorenko, 1999; Ivanenko, 1997; Kulman, 1993; Lysenko et al., 1997; Chumachenko et al., 1978). Unfortunately, generally accepted comprehensive determination of this term, which would completely show its essence, had not been stated till now, which results in some difficulties while developing the conception of the organizational-economic control mechanism of the resource-saving.

According to Y. Lysenko and P. Yegorov "organizational-economic mechanism is a system of setting up objectives and stimuli, which make possible to transform the movement (dynamics) of material and spiritual needs of members of the society during their labor activity into the movement of the production means and its final results directed at the satisfying of the customers payment ability demand (Lysenko et al., 1997). Similar treatment of the organizational-economic 
mechanism is expressed by A. Kozatchenko et al. (2003). The mechanism in this case is treated as a system, that is, the complex of elements, which are in the relations and links with each other and are joint in some integrity, unity. But the process of control is not limited only by the problems of setting up the objectives and stimuli, but is likely to expect the realization of at least three main control functions - planning, organization and control. Moreover, such the most important elements of the control mechanisms as methods and structure of control, have not been analyzed by the authors in the proposed statement, Y. Lysenko and P. Yegorov being reasonable while noting, that "the kernel of the organizational economic mechanism is the system of stimuli, which motivate, make increase the efficiency of the production systems functioning."

Emphasis should be placed on the statement proposed by Y. Astapova (Astapova et al., 2001). The author treats the organizational-economic control mechanism as the system of the organizational and economic elements influence on the management process. In this case the system approach to the statement of the mechanism itself is discovered and detailed with the help of the organizational and economic components.

The statement by Yeryomenko-Hrygorenko 0. (1999), which in great extent is similar to that of the researcher Ivanenko B. (1997) is worthy being mentioned. O. Yeryomenko-Hrygorenko's interpretation of the "organizational-economic control mechanism of the enterprise is a system of technological, economic, organizational and social blocks which include their elements." The researcher presents one more statement of the organizational-economic control mechanism of the enterprise as "the integrity of the social-economic and organizational-economic relations" (Yeryomenko-Hrygorenko, 1999).

More reasonable point of view is that of I. Buleyev (1993), who treats the organizationaleconomic control mechanism as the integrity of forms, methods and instrument of control. Here we can see the description of the control process as well as the means of its application, whereas the term "mechanism" is not interpreted well enough, because "the integrity of forms, methods and instruments" themselves does not result in the transformation of some integrity elements influence on the necessary to change the others.

The notion "mechanism" was borrowed by the economists from mechanics and in its general case means the system of links, which transform the movement of ones into the movement of others, input and output links being available (Universal encyclopedic dictionary, 2000). Basing on this principle reference, the French investigator A. Kulman, while analyzing the economic mechanism in macroeconomic aspect, points out that it can be stated as the necessary interconnection, which appears among different economic phenomena. The mechanism contains some consequence of the economic phenomena, its component elements being input, output phenomena and the whole process simultaneously, which takes place during the intervals between them. The researcher stresses that the mechanism is the system of interconnections of the economic phenomena, which appear under certain conditions being influenced by the initial impulse (Kulman, 1993).

Thus "organizational-economic mechanism of the resource-saving" can be treated as the system of the control elements of the resource-saving (objectives, functions, methods, structure, control subjects) and the control objects of resource-saving, in which purposeful transformation of the resource-saving elements influence on the necessary state or respond of the control objects takes place, and which has its input resources and respond reaction. Thereafter, A. Kulman (1993) states, that "economic mechanism is characterized by either the nature of the initial phenomenon or the final result of phenomena series" and specifies, that "the component elements of the mechanism are both initial and final phenomena simultaneously, and the whole process, which takes place during the interval between them".

Scudar G. M. (2000) points out, that the development of the organizational-economic mechanism requires the system-purposeful approach methodology, states the organizationaleconomic mechanism as the specific multi-functional and multi-component system, which consists of the complex of the interconnected elements, favorable to the influence of the external and internal factors, which form special integrity. These elements are under the single principleproviding the efficient control decision making.

The process of the resource-saving control is carried out like any other management activity in certain operation and procedure consequence, which, as the whole make the technology of the control activity. In the resource-saving control different methods, techniques for the challenges and tasks set up are to be realized, which are included into the method systems of the production control. The organizational-economic mechanism of the efficient resource-saving control within the science of resourcenomy should be treated from our point of view as the organization and control system, which includes some integrity of the interconnected organizational-economic, sociopsychological, standard-legal, technical-technological methods, which are of special importance in some special conditions of the social production, taking into account these peculiarities, the subject 
of control basing on the economic laws and applying economic methods of control, coordinating the private interests with the interests of the object of the control (enterprise, shop, team, individual worker). The latter in its turn, using these methods, plan, organize and carry out their activity in order to reach the challenges set up.

Organizational economic control mechanism at the machine-building enterprise as the integrity of processes and actions to create, provide, operate and improve the system of economic relations between the subjects and objects of the production process is carried out to improve the efficiency of the enterprise activity and the resource-saving in particular. Such control can be efficient due to the application of the organizational and economic factors of the resourcenomy, each of which possessing its own forms of the management activity (Fig. 1).

Figure 1: Formation of the organizational-economic mechanism of the resource-saving at the machine-building enterprise due to the organization-economic levers of the resourcenomy

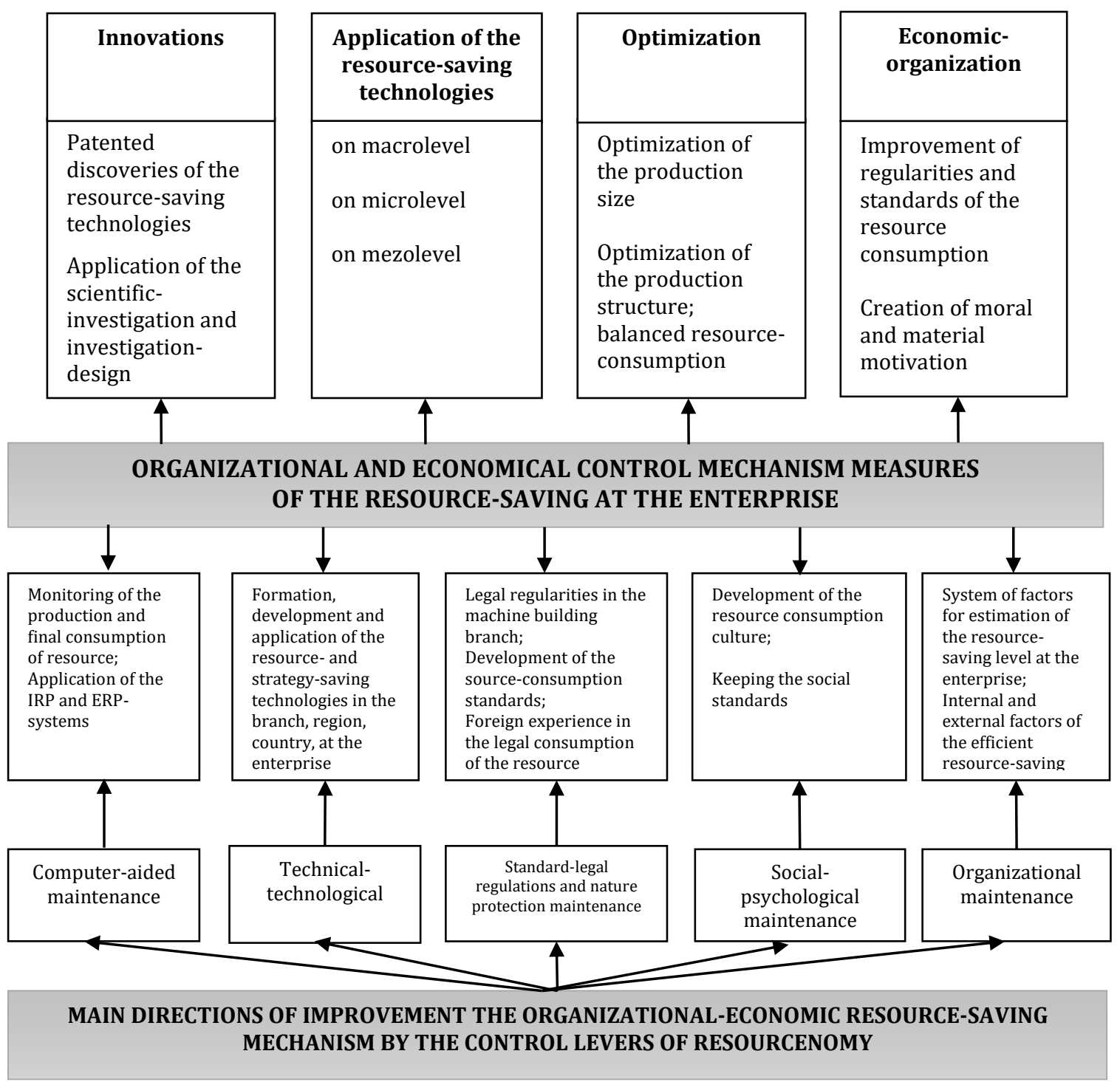

Resource: research findings

In the structure of the organizational-economic mechanism of the resource-saving three systems should be identified: maintenance system, functional and purposeful.

The system of the organization-economic mechanism maintenance consists of the subsystems of legal, standard-methodical, scientific-technological, informational maintenance of the resource-saving control.

Organizational-economic control mechanism of the resource-saving consists of the following functional systems: planning, organization, motivation, control and regulation. Purposeful system of the organizational-economic mechanism of the resource-saving contains challenges and main results of the enterprise activity as well as the choice and estimation criteria of achievement of some challenges and results in resource-saving. As the organizational-economic mechanism of 
resource-saving should be treated as the complex system, which consists of maintenance system, functional and purposeful system, which contain some integrity of the organizational and economic levers and influence the economic and organizational parameters of the resource-saving control, which result in the competition advantages.

With that in mind we propose the innovation chain of stages for the control decision-making in the resource-saving from the point of view of the science of resourcenomy (Fig. 2).

\section{Figure 2: Innovation chain of investigation the control problems of the resource-saving in resourcenomy}

Stages of the control decision-making in resourcenomy (to be continued)

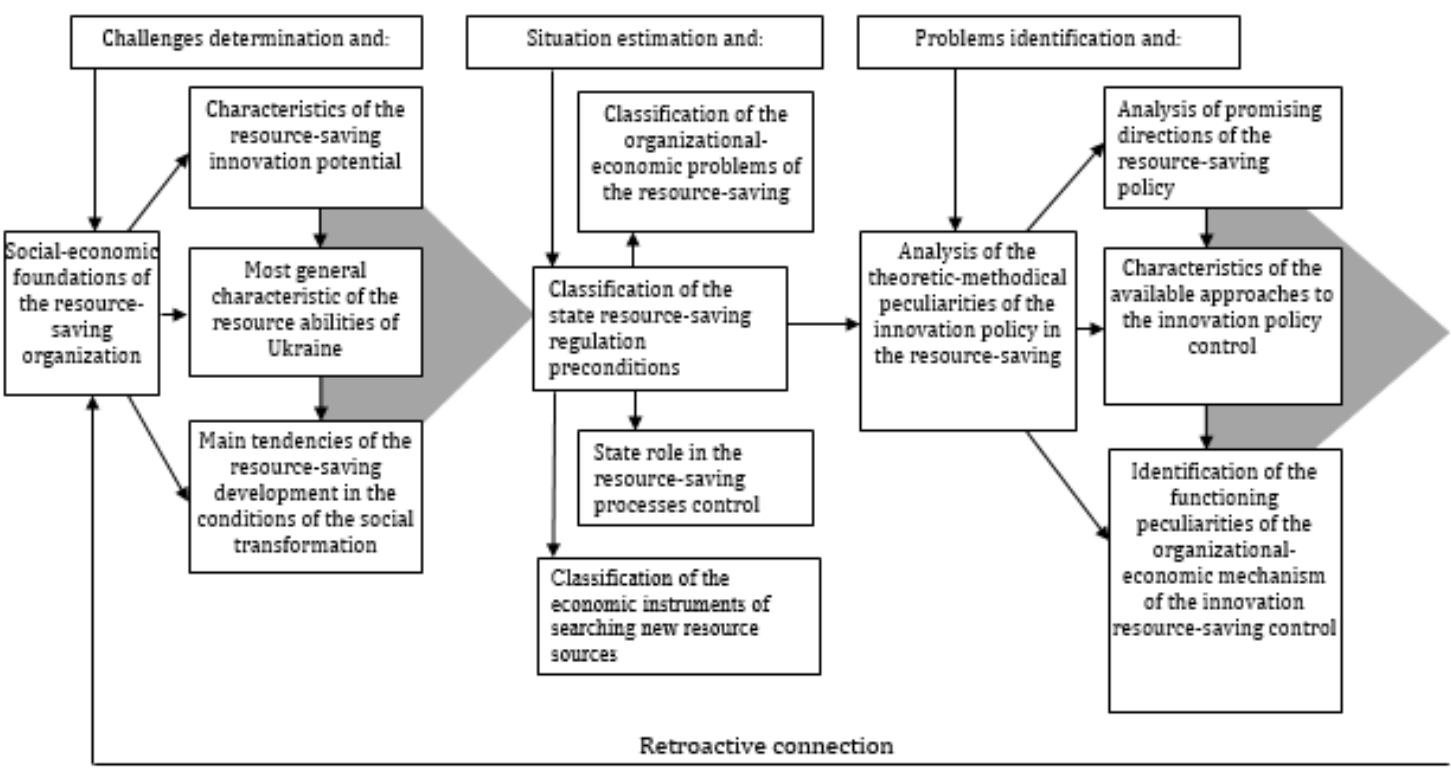

Stages of the control decision-making in resourcenomy

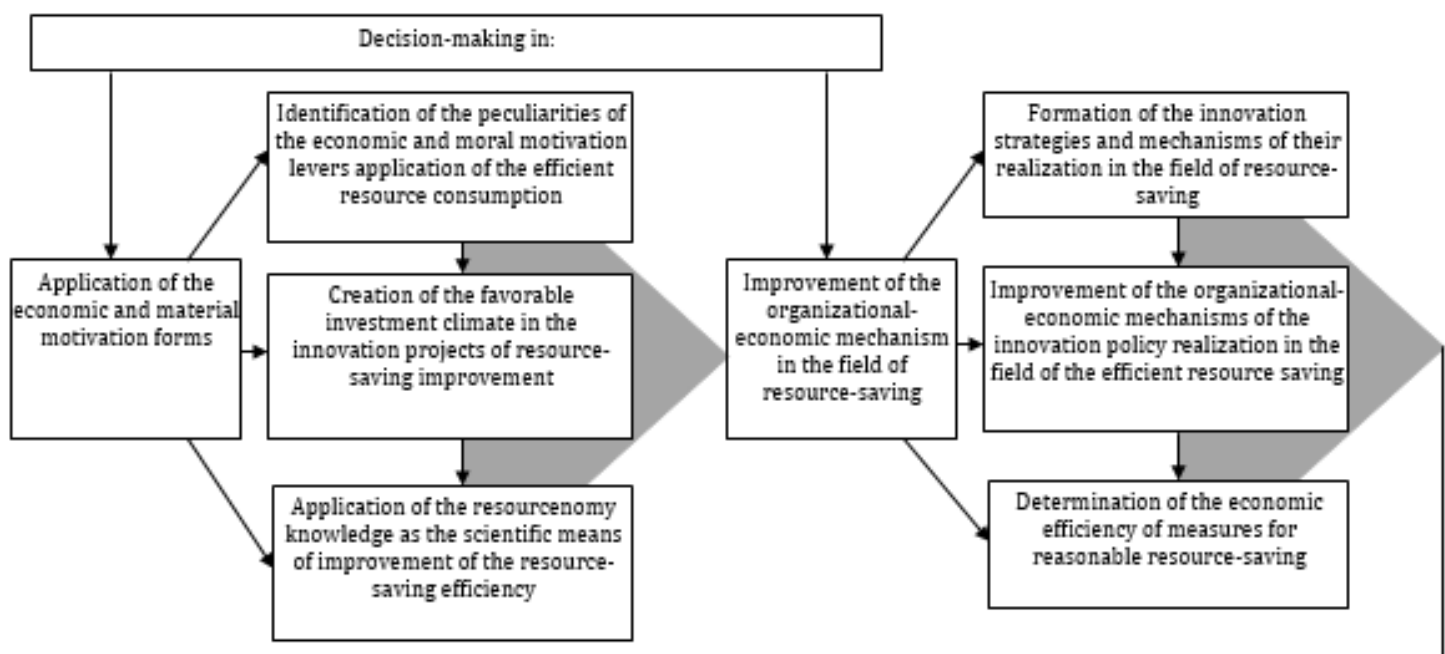

Retroactive connection

\section{Resource: research findings}

Raising of the resourcenomy efficiency in many cases in provided by the perfect control of the resource-saving at the enterprise. In this case it is necessary not only to use the determination of the relative saving of each type of expenditures of the production resources, but the factors, which influence the level of the resource-saving and the resource consumption as well. This approach in its turn results in the increase of the organizational and methodical activity, improvement of the resource audit methods and planning of their consumption. The analysis of investigations in these problems made possible to identify the following factors, which influence 
directly the process of resource-saving in the machine-building field (Andrushkiv et al., 2012; Sotnyk, 2006; Kulman, 1993) (Fig.3).

Figure 3: Resource-saving factors
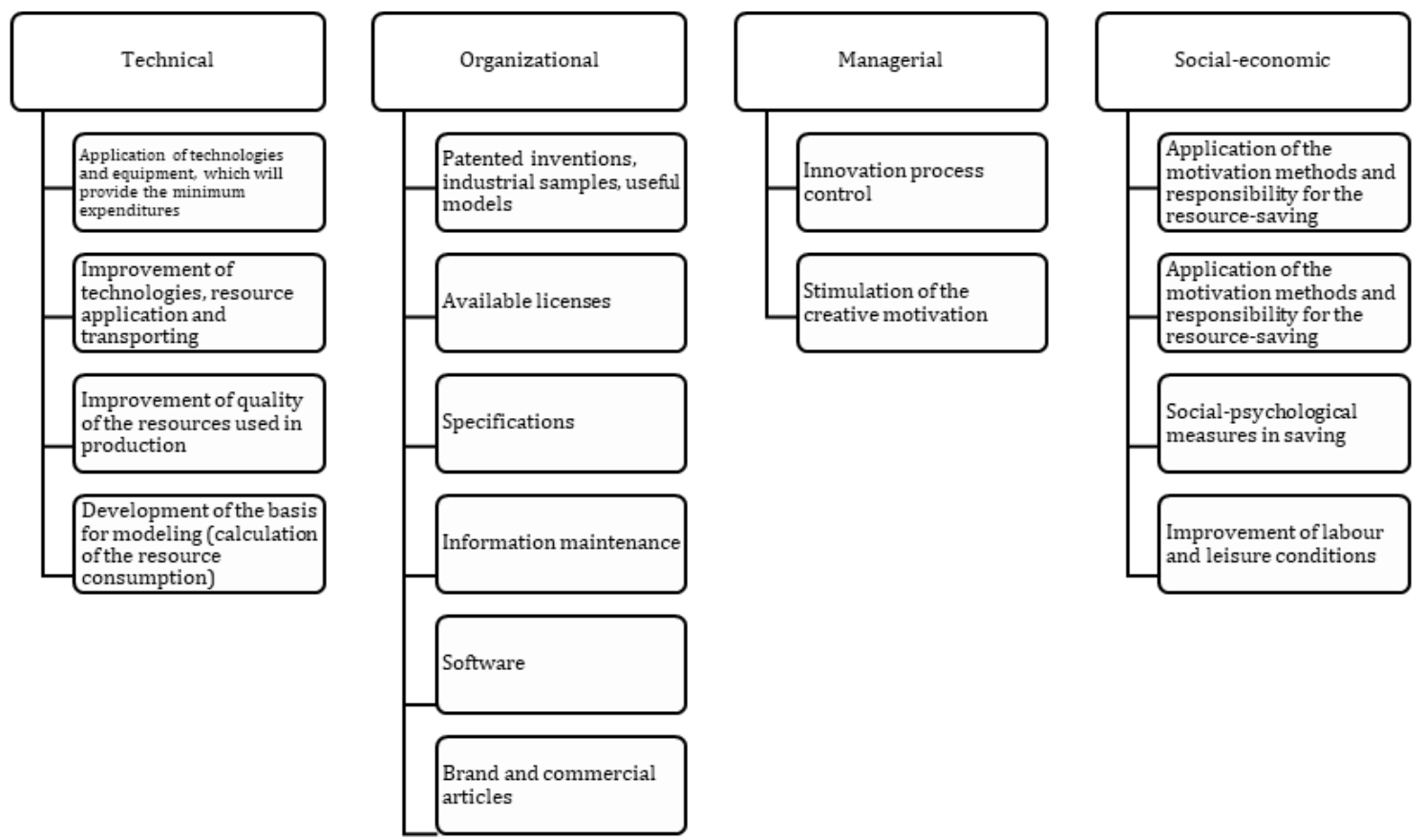

Resource: research findings

In the production-economic systems the development of all elements is the transition from one state into another, which takes place as the result of the conscious, purposeful management activity.

As to the machine-building enterprise in question, the common task is the transition of this system from one state into another (system optimization)/ It means the improvement and replacement of all production elements, all components of the object of control. Transition of the system from one state into another can be of two types (two sides of it): quantitative and qualitative (Deyneko, 1987). Quantitative analysis of the resource-saving consists of the investigation of the resource-saving prospects caused by the development of the scientifictechnological progress, investigation of the resource markets, prediction of the demand and need, determination of the enterprise resource potential. The quantitative analysis deals with the transition to the production more complicated products, raising the machinery and equipment quality and reliability, etc. and is the component part of the economic potential of the enterprise. The methodology of the systematic approach, which results in the proper statement of the problem in investigation and the development of the efficient strategy of its study, is characterized by the fact, that it is oriented on the description of the object and mechanisms integrity, which provide, it for finding different connection types of the complex object and bringing them together into the single theoretical complex. Systematic approach to the control is caused by the specific characteristic of the complex control object and is not limited by the elements characteristic it consists of, and demonstrates itself, first of all, in the characteristics of connections and relations between certain elements (Blauberg, 1997). It makes possible not only to study in details the structure of the investigation object, but to provide the analyses of processes, which take place in it, determining the reasons of their low functioning efficiency. The control mechanism of the resourcesaving is, on one side, the complex of different notions, which are not connected with each other, and on the other - it is the integrity of different elements connected tightly with each other forming the system.

The basis for the control decision-making in the resource-saving should be the factors of the resource-saving control efficiency, i.e. factors that describe the measure of consumption the enterprise resources. Traditionally the efficiency of the enterprise activity is estimated by the system of the economic factors, which characterize in complex the absolute and relative results of its activity, among which the income, volume of gross output, sold output, efficiency indices of the application of all kinds of resources at the enterprise, profitableness indices, amount of saving of the definite kind of the resource or total saving due to the decrease of the cost price of goods 
produced (Zadol'sky, 1995). Most authors identify such groups of indices, which characterize the efficiency if the enterprise resources consumption (Methodology, 1997):

1) generalized indices of the enterprise activity efficiency;

2) indices of the manpower employment efficiency;

3) indices of the production funds exploitation efficiency;

4) indices of the financial resources spending.

Shynkarenko V.G. includes in this list the efficiency indices of the material resources application, circulation means and capital investments of the enterprise (Shynkarenko et al., 2003).

System analyses results in the application of the "purposes tree" method to control the efficiency of the proposed measures. The scheme of the "purposes tree" deals with the structurisation of the problem (Fig. 4).

\section{Figure 4: Scheme of purposes tree for improvement of the organizational-economic} mechanism of the resource-saving

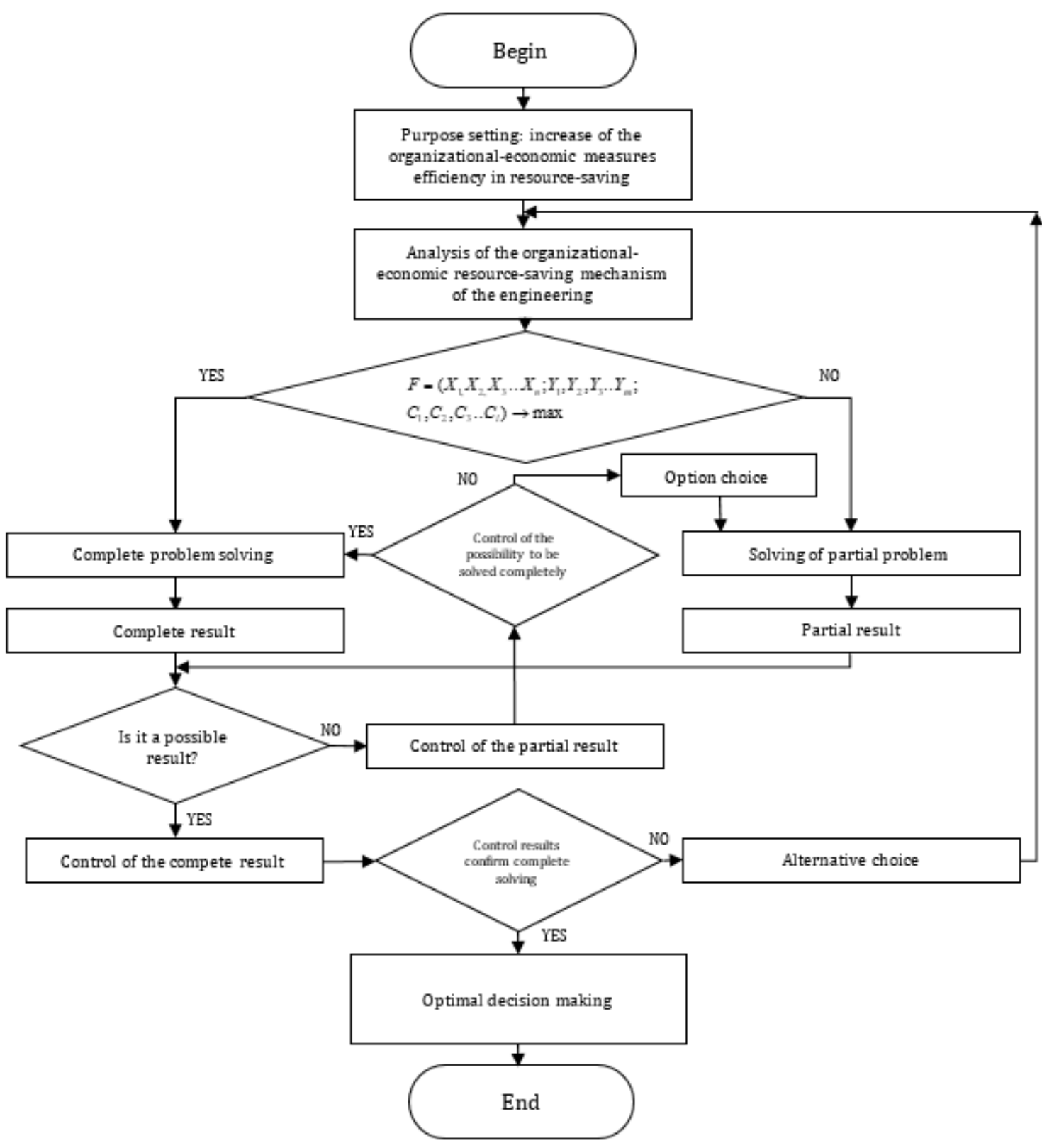

Resource: research findings

Beside partial indices of the resources-consumption efficiency, it is necessary to have the index, which can summarize the information on the level of the resource-saving at the enterprise and help make a control decision on the resource-saving according to its importance.

In the economic literature it is emphasized (Zadolsky, 1995), that the index, which presents this information, is the enterprise income. The income is sure to be the generalized factor, which 
characterizes the financial results of the activity. But the amount of income depends, first of all, on the fact, how the goods produced meet the consuters demands, as well as on its cost price and amount, labor productivity, the level of the production funds exploitation.

That is why the income can not be always treated as the generalized index, because the income increase can be not only due to the most efficient enterprise resource application, but in the case, when the enterprise has the monopoly in certain market. As a result it is worthy introducing such economic theory as the resource-saving measures efficiency to estimate the resource-saving the most precisely.

Efficiency of the enterprise activity is the complex description of the results of resource exploitation application. The estimation of the resource-saving measures efficiency at the machinebuilding enterprise should be treated while realizing that the efficiency is the achievement of the set challenges in the most possible term and with the minimum production resources consumptions.

To choice the most efficient type of the organizational-economic mechanism of the resourcesaving, the interpreting of the taken measures efficiency must be done $(F)$ :

$$
F=\left(X_{1}, X_{2}, X_{3, \ldots} X_{n} ; Y_{1}, Y_{2}, Y_{3} \ldots Y_{m} ; C_{1}, C_{2}, C_{3}, \ldots C_{l}\right) \rightarrow \max
$$

Where

$X_{1}, X_{2}, X_{3, \ldots} X_{n}$ - resource-saving indices;

$Y_{1}, Y_{2}, Y_{3} \ldots Y_{m} ;-$ factors influencing the resource-saving mechanism.

Options of choosing $X_{n}$ are always limited by the external as to the system parameters. Limiting system:

$$
\operatorname{qr}\left(X_{1}, X_{2}, X_{3, \ldots} X_{n} ; Y_{1}, Y_{2}, Y_{3} \ldots Y_{m} ; C_{1}, C_{2}, C_{3}, \ldots C_{l}\right)\{<=>\} 0
$$

it describes internal technological and economic processes of the production-economic system functioning and developing, as well as the processes of the external environment, which influence the result of the system operation.

$$
X_{j}>0,0=1,2, \ldots, n
$$

\section{Conclusions}

The basis of the strategy for the successful activity in the resource-saving at home machinebuilding enterprises is the efficient application of the available resources to meet the requirements for the manufactured products. The most efficient ways of setting up the organizational-economic mechanism of the resource-saving, basing on the qualitative and quantitative indeces of the resources consumption, taking advantage of the resourcenomy levers and taking into account the providing of the enterprise with the equipment, technologies, staff, control system, as well as the influence of each of the factors of the internal and external enterprise environment, are proposed to be determined.

\section{Appendix A. Supplementary material}

Supplementary data associated with this article can be found, in the online version, at https://dx.doi.org/10.14254/jems.2017.2-2.1

\section{Funding}

The authors received no direct funding for this research.

\section{Citation information}

Vovk, I., Vovk, Yu., \& Lyashuk, O. (2017). Improvement of the organizational-economic mechanism of resource-saving at the machine building enterprise. Economics, Management and Sustainability, 2(2), 6-14. doi:10.14254/jems.2017.2-2.1

\section{References}

Ahenstvo z Pytan Zapobihannya Bankrutstvu Pidpryyemstv ta Orhanizaciy. (1997). Methodology of basic analyses of insolvent enterprises and organizations financial economical state. Number 
81 of 27.06.97. Retrieved from http://zakon3.rada.gov.ua/laws/show/z0288-97. [in Ukrainian].

Andrushkiv, B. M., Vovk, I. P., Vovk, Yu. Ya., Palyanytsya, V. A., Pohaydak, O. B., \& Stoyko, I. I. (2012). Resourcenomy: Theoretical and practical aspects (Monograph). Ukraine, Ternopil: Ternograph Ltd. ISBN 978-966-457-121-7. Retrieved from https://www.researchgate.net/ publication/277308489_Resursonomika_teoreticni_ta_prikladni_aspekti. [in Ukrainian].

Astapova, G. V., Astapova, E. A., \& Loyko, D. P. (2001). Organizational economical mechanism of corporative management under the modern condition of Ukrainian economy reformation. Donetsk: Donetsk National University of Economy and Commerce named after Tugan Baranovsky. [in Russian].

Berzin, I. E., Zaharova, M. K., \& Kalinin, V. P. (1979). Machine building enterprises management (Engineer Economical Monograph). Moscow: Machinebuilding. [in Russian].

Blauberg, K. V. (1997) Integrity problems and system approach. Moscow. [in Russian].

Buleyev, I. P. (1993). Colored metals treatment enterprises management organizational economical mechanism formation. Donetsk: Academy of Sciences of Ukraine. [in Russian].

Chumachenko, N. G., Savchenko, A. P., \& Kornyeyev, V. G. (1978). Making decisions in enterprise management. Kyiv: Technica. [in Ukrainian].

Deyneko, O.A. (1987). Technology of managing activity in machine building, Moscow, Machinebuilding, 192 P. [in Russian].

Ivanenko, B. M. (1997). The Formation of working unity functioning organizational economical mechanism under the market condition (Candidate of economy science dissertation abstract of thesis 08.06.01). Donetsk: Academy of sciences of Ukraine, Institute of Industrial Economy. [in Ukrainian].

Kozachenko, A. V., \& Guskova, O.V. (2003). Principal approaches to knowledge in modern enterprises management organization. Prometey, 3(12), 95-105. [in Russian].

Kulman, A. (1993). Economical mechanisms. Moscow: Publishing Group "Progress", "Univers”. [in Russian].

Lysenko, Y., \& Yegorov, P. (1997). Organizational economical mechanism of enterprise management. Economy of Ukraine, 1, 86-87. [in Russian].

Shynkarenko, V. G., \& Bondarenko, A. S. (2003). Enterprises competitiveness management. Kharkov: Publishing house of Kharkov National Academy of State Management, 186 P. [in Russian].

Skupar, G. M. (2000). Organizational economical mechanism of enterprise competitiveness management (Candidate of economy science dissertation abstract of thesis 08.06 .03 "Economy regulation, management and planning organization"). Donetsk. [in Ukrainian].

Sotnyk, I., ed. (2006). Resources maintenance and economical development of Ukraine: Ukraine subjects of manage transformation mechanisms formation on the basis of resources maintenance technologies (Monograph). Sumy: Universytetska knyha. [in Ukrainian].

Universal encyclopedic dictionary. (2000). Moscow: Bolshaya Rossiyskaya Entsyklopediya. [in Russian].

Yeryomenko-Grygorenko, O. A. (1999). Organization economical mechanism of an enterprise economic activity management (Dissertation work of the candidate of economy science 08.06.01). Donetsk: Academy of Science of Ukraine, Institute of Industrial Economy. [in Russian].

Zadolsky, A. (1995). Enterprise activity effectiveness evaluation. Economica Ukrainy, 12, 79-81. [in Russian].
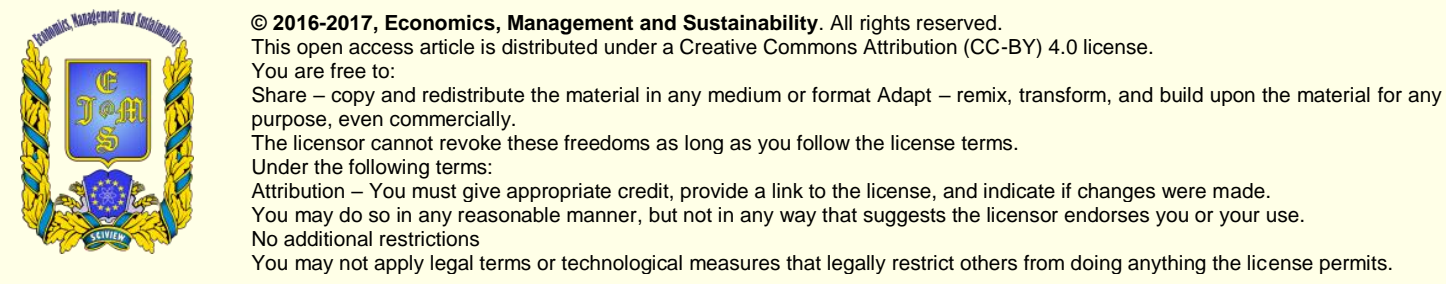

Economics, Management and Sustainability (ISSN: 2520-6303) is published by Scientific Publishing House "CSR", Poland, EU and Scientific Publishing House "SciView", Poland

Publishing with JEMS ensures:

- Immediate, universal access to your article on publication

- High visibility and discoverability via the JEMS website

- Rapid publication

- Guaranteed legacy preservation of your article

- Discounts and waivers for authors in developing regions

Submit your manuscript to a JEMS at https://jems.sciview.net or submit.jems@sciview.net 